\title{
Histomorphology and Histochemistry of adrenal cortex of adult Bakerwali goat of Jammu region
}

\author{
S. Suri, G. Kour and J.S. Sasan*
}

Division of Veterinary Anatomy, Faculty of Veterinary Sciences \& Animal Husbandry, Sher-EKashmir University of Agricultural Sciences \& Technology of Jammu, R.S. Pura, J\&K.

*E-mail: jssasan216@gmail.com

Journal of Livestock Science (ISSN online 2277-6214) 13: 80-87

Received on 23/9/21; Accepted on 3/2/22; Published on 5/2/22

doi. 10.33259/JLivestSci.2022.80-87

\begin{abstract}
The present study was conducted on the adrenal gland of adult Bakerwali goat. Glands were fixed in fixative (10\% neutral buffered formalin and zenker's fixative). The adrenal glands were paired (right and left), reddish-brown, ductless glands situated in the roof of the abdomen. The right adrenal gland was pyramidal in shape. The left adrenal gland was strongly curved and elongated. The cortex consisted of three zones i.e. zona glomerulosa, zona fasciculate and zona reticularis. Zona glomerulosa had two parts: the superficial zona glomerulosa and deep zona glomerulosa. The zona glomerulosa exhibited intense reactivity for mucopolysaccharide and for lipid granules. The zona fasciculate was broadest zone of the adrenal cortex. The percentage of cortical area occupied by this zone was $55.40 \%$ in right adrenal gland and $54.29 \%$ in left adrenal gland. The intracapsular and extracapsular accessory adrenal nodules were found in the present study. The adrenal nodules have been surrounded by the capsule of dense irregular connective tissue fibers mainly comprised of collagen fibers and reticular fibres.
\end{abstract}

Keywords: adrenal cortex; adrenal nodules; Bakerwali goat; histomorphology; histochemistry 


\section{Introduction}

Goat is one of the oldest domesticated animals which provide meat, milk, wool, hide and fur for human use. In India goats require very less investment and can be reared easily in marginal or undulating lands unsuitable for other types of animals like cow or buffalo so are called as 'poor man's cow' (Sastry and Thomas 2005). Goats are reared by population which is on fringe of development scale across the continents from Western Africa to fareast Asia for their as a sole or supportive income (Ogbuewu et al. 2016; Salvana et al 2019). Bakerwali goat constitutes about 50\% of total goat population of Jammu \& Kashmir (Gupta and Bakshi 2009). This state is ideally suited for rearing of goats owing to its agro-climatic and geo-physical conditions. Nature has bestowed this state with tall mountains to low hills and vast meadows which provide enormous scope and excellent atmosphere for goat rearing. It is mainly found in hilly tracts of Poonch, Jammu, Rajouri, Udhampur and Kathua. Bakerwali goats are migratory type of animals as these animals move downwards to the plain areas in the end week of September or in the first week of October and then move back to hills in the ending of March or first week of April. Because of this migratory behavior of the animals they come under stress and the adrenal gland play an important role in maintenance of stress by secreting some hormones like cortisol.

Adrenal glands are paired organs located within the abdominal cavity (Ahmadpanahi 2006). The adrenal gland consist of two main areas i.e. cortex at the periphery covered by capsule and medulla in the center. These two functional and anatomical units of adrenal gland are of different embryological origin: the mesodermal cortex and the neural crest ectoderm derived medulla (Eurell and Frappier 2006).

The adrenal cortex constitutes about $90 \%$ of the gland mass and divided from the outer to the inner part into three distinct zones: zona glomerulosa, zona fasciculata and zona reticularis. The cells of the outermost region of the adrenal cortex i.e. the zona glomerulosa, are source of mineralocorticoid. The zona fasciculata is the thickest layer of the adrenal cortex consists of polyhedral cells and is a source of glucocorticoid. The zona reticularis typically borders the adrenal medulla, contains numerous reticular fibers and synthesize small amount of androgens (Eurell and Frappier 2006). The hormones secreted by the adrenal glands regulate a number of metabolic processes like circadian rhythm, alterations in the circadian rhythm, stress responsiveness, feedback inhibition, regulation of androgen production etc. which enable animals to function in a constantly changing environment. Due to scarcity of literature on gross anatomy, histomorphology and histochemistry of adrenal cortex of this important breed of goat of Jammu region, this study has been planned.

\section{Materials and methods}

The study was conducted on the adrenal glands of 50 apparently healthy adult Bakerwali goats (irrespective of sex). The adrenal gland of Bakerwali goats were collected immediately after slaughter from the slaughter house of Gujjar Nagar, Dogra hall slaughter house, local butcher shop at Gandhi Nagar and local butcher shop at Miran Sahib. The specimen was brought to the laboratory in ice as early as possible.

Gross morphology of the gland was studied. The shape index of right and left adrenal glands was calculated by using the formula:

Shape Index (\%): Width/ length X 100 ( Barnwal and Sinha,1981)

The adrenal glands were preserved and fixed in $10 \%$ neutral buffered formaline (Singh and Sulochana 1978) and in zenker's fixative (Luna 1968). After achieving the complete fixation, the adrenal gland was processed by alcohol-benzene schedule (Luna 1986) to prepare blocks. Tissue sections of $5 \mu \mathrm{m}$ were obtained from these blocks on clean glass slides with the help of rotary microtome.

The paraffin sections were stained with various histological and histochemical to record the histomorphological and histochemical features. For routine histomorphology, Hematoxylin and Eosin stain was used (Luna 1986). For connective tissue fibers, Verhoeff's with Von Gieson stain (Mallory 1942) and Mason's Trichrome stain was used (Luna 1968). Sudan Black B was used for the demonstration of lipids, Periodic Acid Schiff's stain for demonstration of Neutral muco-polysaccharides and Schultz method was used for cholesterol demonstration (Luna 1968).

\section{Results and discussion}

\section{Gross anatomy and biometry}

The adrenal glands were paired (right and left), reddish-brown, ductless glands situated in the roof of the abdomen (Fig. 1). The adrenal glands of Bakerwali goats were flattened from side to side and elongated from backwards while Nwaogu et al. (2009) observed that the adrenal glands were oval in shape and were reddish-brown 
in Kano brown goat. The right adrenal gland was pyramidal in shape as also observed by Nandeshwar et al. (2017) in goat whereas Ashok et al. (2005) observed roughly triangular right adrenal gland in crossbred goats. It lies in contact with the antero-medial part of the right kidney and it also occupied a part of renal impression on the liver of the adult Bakerwali goat. Its external surface was convex and lies in the renal impression of the liver. The shape index of right adrenal gland was $48.66 \pm 1.58 \%$.

The left adrenal gland was not in contact with the kidney and lies at some distance infront of the kidney, almost near to medial aspect of the corresponding kidney (Fig. 1). Nama et al. (2009b) observed that the adrenal gland of Marwari sheep were pale pink, smooth, flattened bodies situated retroperitonially cranially to each kidney in the dorso-caudal part of the abdominal cavity. It was strongly curved and elongated. Similar results were observed by Ashok et al. (2005) in crossbred goat. The anterior extremity was small and round. The posterior extremity was also rounded but it was thick and wide (Fig. 2). Nama et al. (2009b) found that the left adrenal gland was free at rostral pole of left kidney in Marwari goat. The shape index of left adrenal gland was $62.35 \pm 1.85 \%$.

\section{Histomorphology and histochemistry}

The adrenal glands of adult Bakerwali goat consisted of two distinct parts the stroma and the parenchyma. The stroma consisted of the capsule and the trabeculae and parenchyma consisted of the outer adrenal cortex and inner adrenal medulla (Fig. 2). Similar observations were given by Eurell and Frappier (2006) in domestic animals. Nama et al. (2009a) described that the parenchymal tissue of adrenal gland of Marwari goat was clearly identifiable into cortex and medulla like other domestic animals.

\section{Adrenal Cortex}

The cortex consisted of three zones i.e. zona glomerulosa, zona fasciculata and zona reticularis (Fig. 2) as earlier given by Eurell and Frappier (2006) in domestic animals. The zona glomerulosa constituted the outer cortex and the zona fasciculata and zona reticularis form the inner cortex. Similar trend was given by Eurell and Frappier (2006) in domestic animals. The zones of adrenal cortex were not sharply demarcated but gradually merge into one another. Among the three zones of the adrenal cortex, the zona fasciculata was the largest zone followed by zona reticularis and the smallest zone was zona glomerulosa as also reported by Wheater et al. (1994) in human being. Similarly Nwaogu et al. (2009) also observed that the adrenal cortex comprised of three zones with the zona fasciculate as the largest zone in adult Kano brown goat. The collagen and reticular fibers were predominantly seen among the cells of different zones of adrenal cortex. The adrenal cortex showed moderate reaction for carbohydrate, lipid and cholesterol. In the present study the adrenal cortex showed more strong reaction for mucopolysaccharides than in adrenal medulla as was also reported by Kumar et al. (2011) in buffalo owing to secretions of glucocorticoid.

\section{Zona Glomerulosa}

Zona glomerulosa was the first and the smallest zone of the adrenal cortex lying just below the adrenal capsule (Fig. 3). Zona glomerulosa exhibited two parts: the superficial zona glomerulosa and deep zona glomerulosa (Fig. 4). Bacha and Bacha (1990) recorded that a zona intermedia occurs between the zona glomerulosa and zona fasciculata in the adrenal gland of carnivores. The cells of the zona glomerulosa were columnar in shape and arranged in irregular cords separated by delicate trabeculae containing wide diameter capillaries (Fig. 3). Bacha and Bacha (1990) observed that the cells of zona glomerulosa were arranged into irregular groups and cords in ruminants. Nama et al. (2009a) in Marwari goat and Shehan et al. (2017) in local Iraqi goat reported that the zona glomerulosa was underneath the capsule and comprised of irregular clusters of cuboidal cells with centrally placed oval to rounded nuclei. The cells which were adjacent to the capsule were arranged in more irregular manner (Fig. 4) than the cells of deeper zone. Few cells of zona glomerulosa were found encapsulated within the trabeculae of adrenal gland. Panchal et al. (1998) reported that the encapsulated groups of some cortical cells of zona glomerulosa were found within the capsule of the gland in Marwari sheep. The cytoplasm of the cells of zona glomerulosa was eosinophillic whereas the nuclei were strongly basophilic whereas Panchal et al. (1998) recorded that the cytoplasm of zona glomerulosa cells was eosinophilic with many large vacuoles in Marwari sheep.

The size of cells and diameter of nucleus of this zone was greater in left adrenal gland $(17.82 \pm 0.25 \mu \mathrm{m}$ and $15.17 \pm 0.25 \mu \mathrm{m}$, respectively) (Table 1) while Nama et al. (2009a) described lower values for the same parameters which may be due to species difference. Kumar et al. (2009) recorded the average cell size in zona glomerulosa $16.37 \pm 0.12 \mu \mathrm{m}$. The percentage of cortical area occupied by zona glomerulosa was $17.71 \%$ (Table 3 ) whereas Nama et al. (2009a) found that percentage of cortical area occupied by zona glomerulosa was $4.58 \%$ in Marwari sheep which was almost one fourth of the values recorded in Bakerwali goat. The percentage of area occupied by zona glomerulosa was $12.70 \%$ in Teddy goats (Qureshi et al. 2012). The density of cells per unit field in left adrenal gland was $146.05 \pm 2.50$ whereas in right adrenal gland it was $121.79 \pm 1.50$ (Table 2), on the other hand, Kumar et al., (2009) found that the average density of cells per unit area in zona glomerulosa was $41.78 \pm 3.00$ in buffalo. 


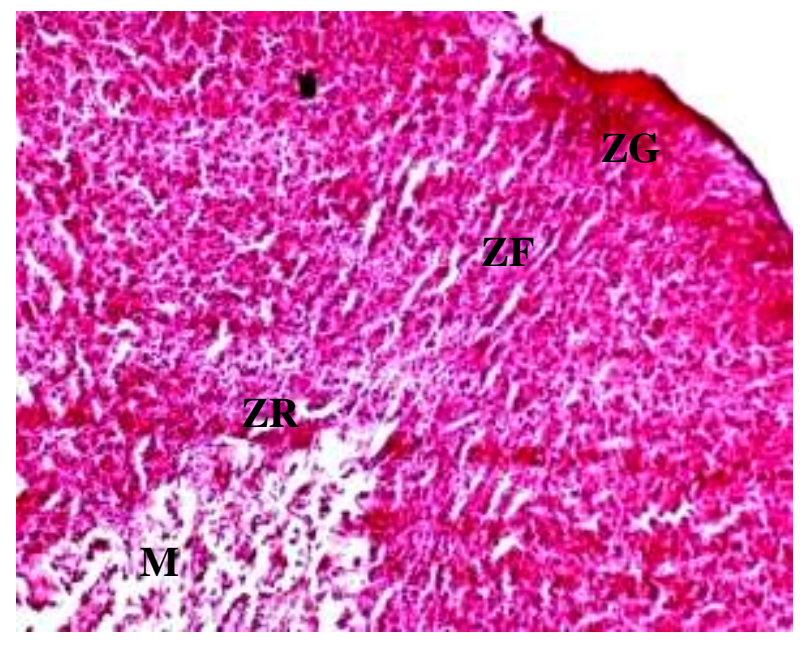

Fig 1: Adrenal gland of adult Bakerwali goat showing three layers of outer adrenal cortex i.e. zona glomerulosa (ZG), zona fasciculate (ZF), zona reticularis $(\mathrm{ZR})$ and inner medulla $(\mathrm{M})$ (Vongieson \& Verhoeff $\mathrm{X} 100)$.

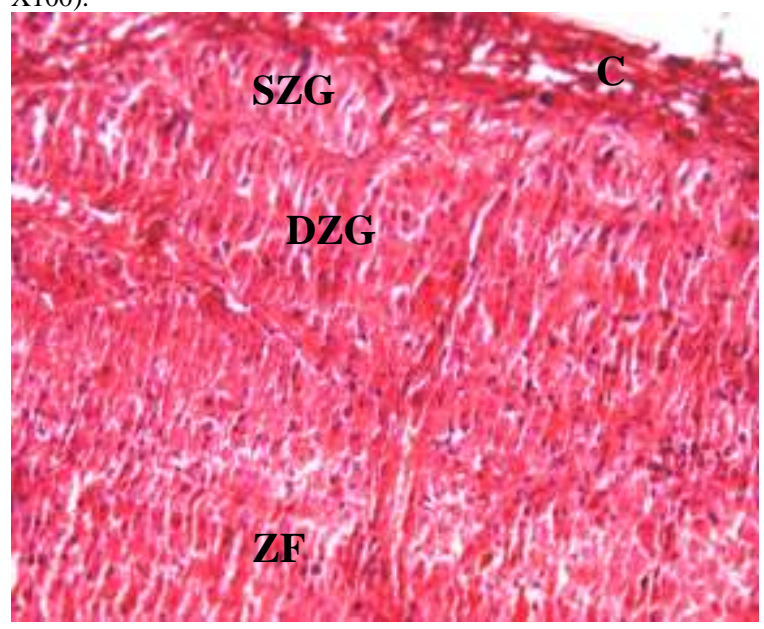

Fig 3: Adrenal gland of adult Bakerwali goat showing capsule (C), two zones of zona glomerulosa, the superficial zona glomerulosa (SZG) and the deep zona glomerulosa( DZG) (H\&E X 100)

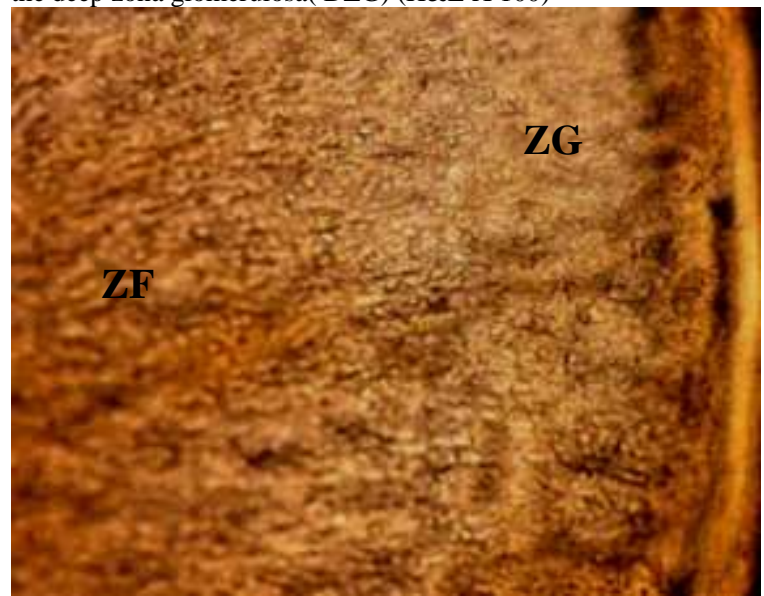

Fig 5: Adrenal gland of adult Bakerwali goat showing presence of cholestrol in zona glomerulosa (ZG). (Schultz method X100).

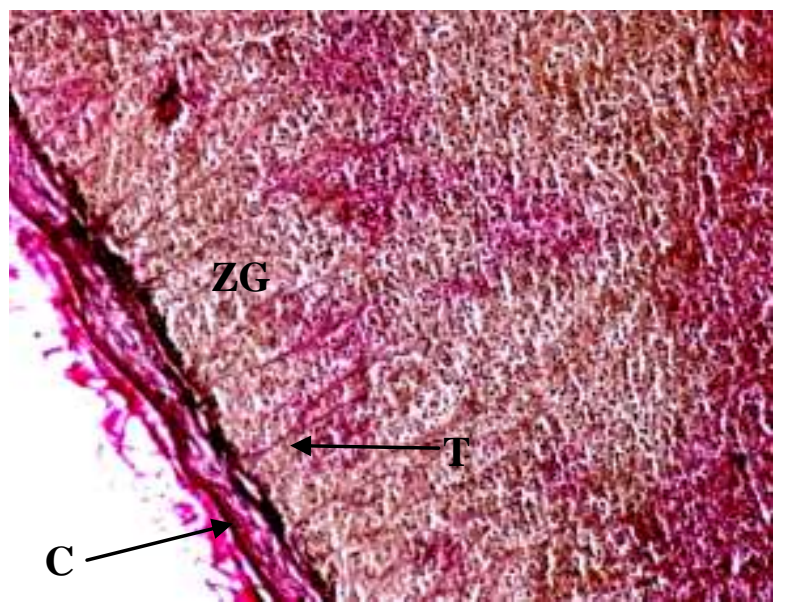

Fig 2: Adrenal gland of adult Bakerwali goat showing presence of collagen and reticular fibres in the capsule $(\mathrm{C})$, trabeculae $(\mathrm{T})$ extend into zona glomerulosa (ZG). (Vongieson \& Verhoeff X 100)

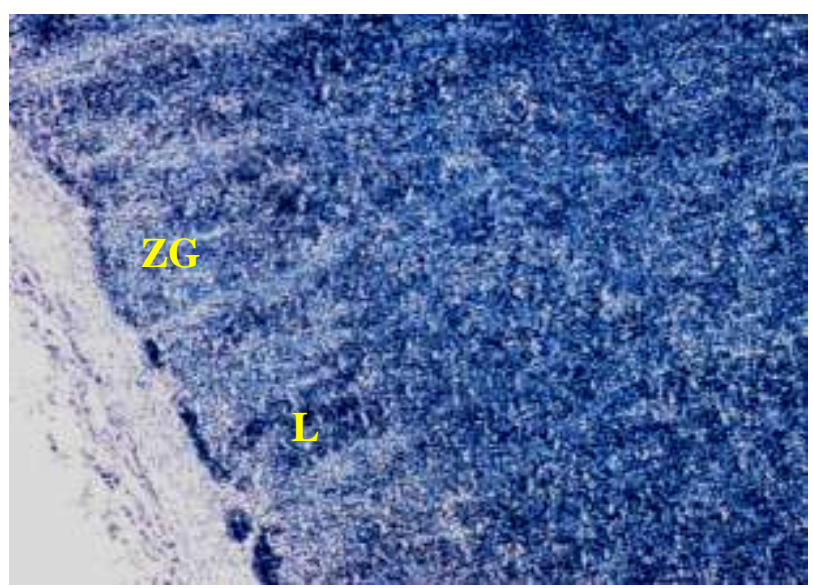

Fig 4: Adrenal gland of adult Bakerwali goat showing presence of lipids (L) in some areas of the zona glomerulosa (ZG) (Sudan Black $\mathrm{X} 100)$

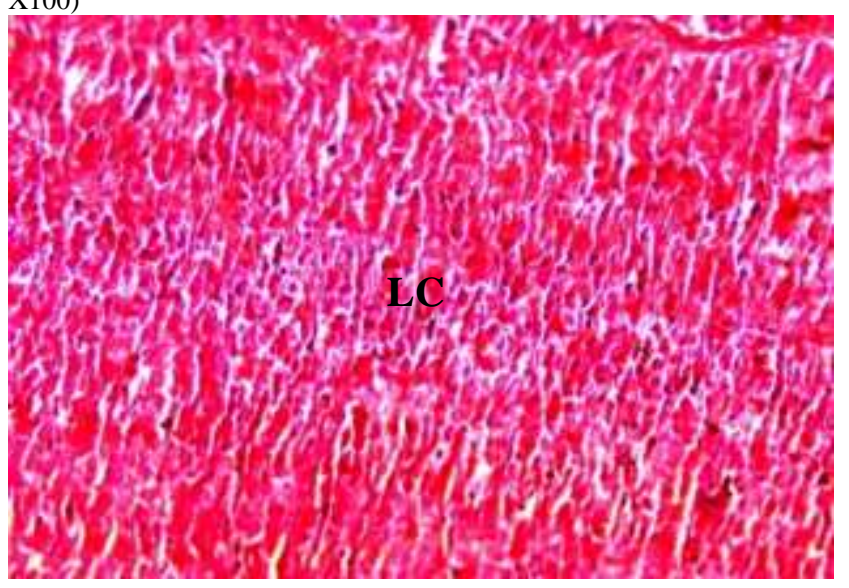

Fig 6: Adrenal gland of adult Bakerwali goat showing the typical arrangement of zona fasciculata in the form of longitudinal cords(LC)( H\&E X 100) 


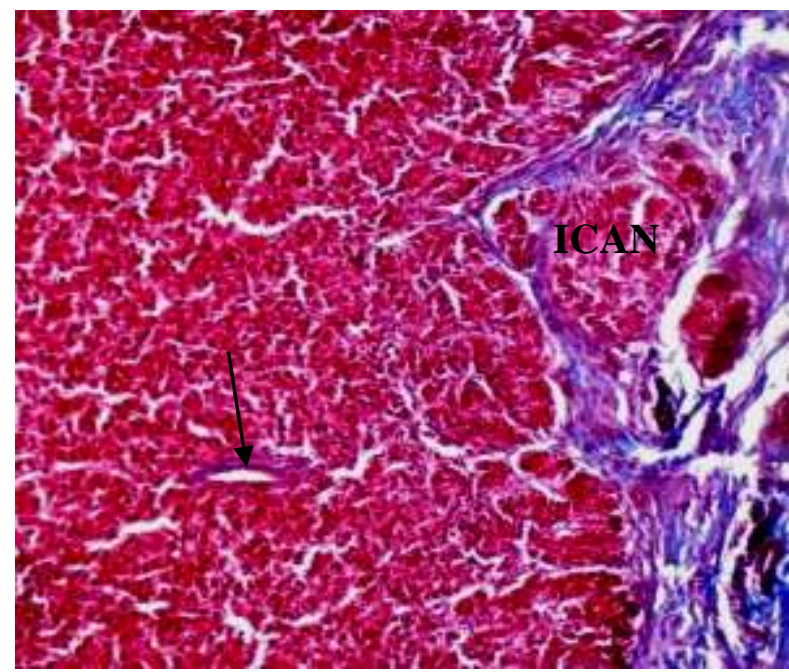

Fig 7: Adrenal gland of adult Bakerwali goat showing presence of blood vessel (arrow) in zona glomerulosa and inracapsular adrenal nodules (ICAN) (Masson's trichrome X 100)

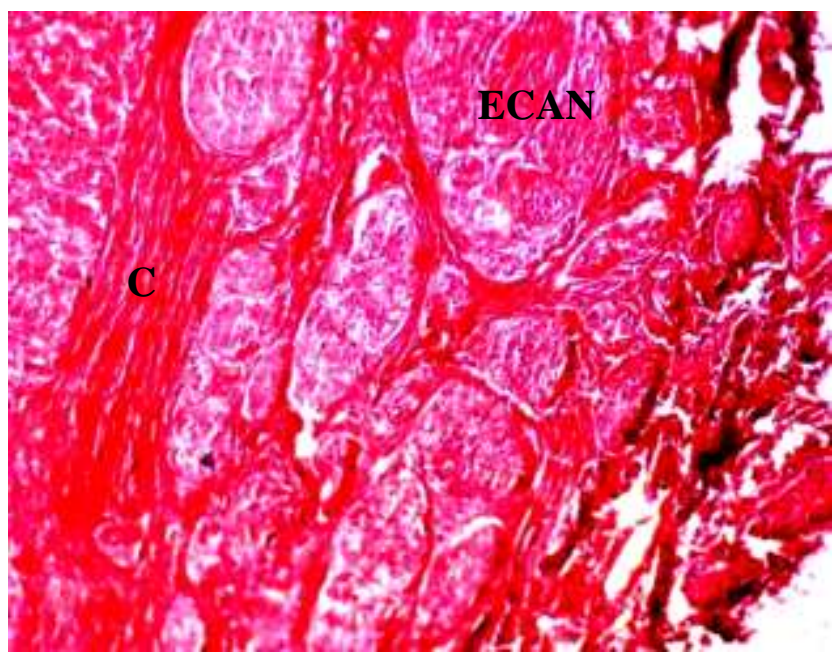

Fig 8: Adrenal gland of adult Bakerwali goat showing presence of extra capsular adrenal nodules (ECAN) (H \& E X100)

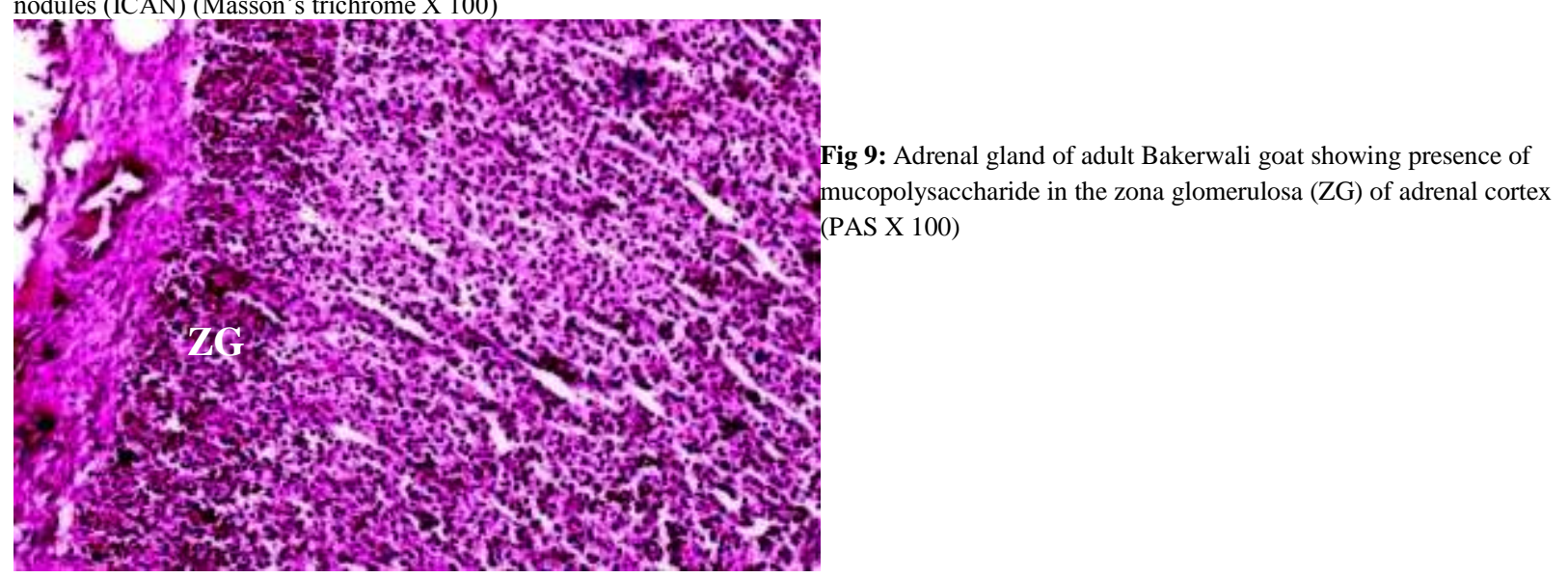

The zona glomerulosa exhibited intense reaction for mucopolysaccharide (Fig 10) whereas other two zones of adrenal cortex showed moderate reaction. Similarly Kumar et al. (2011) reported that PAS positive reaction in the cells of zona glomerulosa was due to presence of glycogen. The adrenal cortex showed strong reaction to sudanophillic lipid granules than in the adrenal capsule while the adrenal medulla exhibited only mild reactivity contradictory to the findings of Kumar et al. (2011) in buffalo adrenal gland. The intensely reactive lipid granules were also observed at some places of zona glomerulosa (Fig 5) whereas Kumar et al. (2011) observed the evenly distributed lipid granules in this zone of adrenal gland of buffalo. The cholesterol reaction was observed in the zona glomerulosa (Fig. 6) in contrast to the findings of Kumar et al. (2011) in which high amount of cholesterol was present in zona fasciculata. The adrenal capsule and trabeculae exhibited mild reactivity for lipids.

\section{Zona Fasciculata}

The zona fasciculata was the middle and the broadest zone of the adrenal cortex (Fig. 2) as was also reported by Wheater et al. (1994) in humans, Nama et al. (2009b) in Marwari goat and Shehan et al. (2017) in local Iraqi goat. It occupied more than half of the total cortical thickness (Table 3). The cells of this zone were arranged in distinctively longitudinal cords that radiate towards the medulla and were separated by sinusoids (Fig. 7). This zone had coarse collagen fibers distributed between the cords. The cytoplasm of spherical cells of zona fasciculata was highly eosinophillic with rounded basophilic nuclei. The zona fasciculata appeared foamy, because of the presence of numerous lipid vacuoles. Similar observations were made by Nama et al. (2009b) in Marwari goat and Sanyal et al. (2005) in goat. The trabeculae of right adrenal gland extended up to this zone. Nama et al, (2009b) described that the zona fasciculate cells were cuboidal with centrally placed nuclei and arranged in radiating columns in Marwari goat. Nwaogu et al. (2009) observed that the cells of zona fasciculate were arranged in a cord-like pattern running 
Table 1: Different histomorphological and histochemical stains used in paraffin section of adrenal gland Histomorphological stains

\begin{tabular}{|l|l|l|}
\hline \multicolumn{1}{|c|}{ Purpose } & \multicolumn{1}{c|}{ Stain } & \multicolumn{1}{c|}{ Source } \\
\hline Routine histomorphology & Haematoxylin and Eosin & Luna (1968) \\
\hline Elastic and collagen fibres & Verhoeff's with Von gieson stain & Mallory (1942) \\
\hline Collagen fibres & Masson's trichrome method & Luna (1968) \\
\hline
\end{tabular}

Histochemical stains

\begin{tabular}{|l|l|l|}
\hline Lipid & Sudan black B stain & Luna (1968) \\
\hline Neutral muco-polysaccharides & Periodic Acid Schiff's stain & Luna (1968) \\
\hline Cholesterol & Schultz method & Luna (1968) \\
\hline
\end{tabular}

Table 2: Micrometry of cells of different zones of adrenal cortex in adult Bakerwali goats (Mean \pm SE)

\begin{tabular}{|l|l|l|l|}
\hline \multicolumn{2}{|c|}{ Parameters } & \multicolumn{1}{c|}{ Right $(\mu \mathrm{m})$} & \multicolumn{1}{c|}{ Left $(\mu \mathrm{m})$} \\
\hline \multirow{4}{*}{ Cell size } & Zona glomerulosa & $16.29 \pm 0.33^{\mathrm{a}}(13.00-20.00)$ & $17.82 \pm 0.26^{\mathrm{b}}(15.00-20.00)$ \\
\cline { 2 - 4 } & Zona fasciculate & $16.35 \pm 0.27^{\mathrm{a}}(14.00-20.00)$ & $17.97 \pm 0.24^{\mathrm{b}}(15.00-20.00)$ \\
\cline { 2 - 4 } & Zona reticularis & $11.02 \pm 0.23^{\mathrm{a}}(9.00-14.00)$ & $18.47 \pm 0.23^{\mathrm{b}}(16.00-20.00)$ \\
\hline \multirow{2}{*}{$\begin{array}{l}\text { Nuclear } \\
\text { diameter }\end{array}$} & Zona glomerulosa & $10 \pm 0.24(8.00-13.00)$ & $15.17 \pm 0.25(12.00-18.00)$ \\
\cline { 2 - 4 } & Zona fasciculate & $10.67 \pm 0.26^{\mathrm{a}}(9.00-14.00)$ & $15.32 \pm 0.24^{\mathrm{b}}(13.00-18.00)$ \\
\cline { 2 - 4 } & Zona reticularis & $9.05 \pm 0.24^{\mathrm{a}}(7.00-12.00)$ & $16 \pm 0.19^{\mathrm{b}}(14.00-18.00)$ \\
\hline
\end{tabular}

Values with different superscript $(a, b)$ differ between the left and right adrenal glands significantly $(\mathrm{P}<0.05)$.

Table 3: Density of cells per field in adrenal cortex in adult Bakerwali goats (Mean \pm SE)

\begin{tabular}{|l|l|l|}
\hline \multicolumn{1}{|c|}{ Parameters } & \multicolumn{1}{c|}{ Right } & \multicolumn{1}{c|}{ Left } \\
\hline Zona glomerulosa & $121.79 \pm 1.50^{\mathrm{a}}(105.0-134.0)$ & $146.05 \pm 2.50^{\mathrm{b}}(121.0-180.0)$ \\
\hline Zona fasciculata & $121.52 \pm 1.25^{\mathrm{a}}(110.0-138.0)$ & $135.44 \pm 1.61^{\mathrm{b}}(120.0-165.0)$ \\
\hline Zona reticularis & $124.23 \pm 0.80(110.0-130.0)$ & $154.20 \pm 1.20(132.0-160.0)$ \\
\hline
\end{tabular}

Values with different superscript $(a, b)$ differ between the left and right adrenal glands significantly $(\mathrm{P}<0.05)$.

Table 4: Percentage of area occupied by different zones of adrenal cortex in adrenal glands of adult Bakerwali goats

\begin{tabular}{|l|c|c|}
\hline \multicolumn{1}{|c|}{ Parameters } & Right $(\%)$ & Left (\%) \\
\hline Zona glomerulosa & 17.71 & 16.65 \\
\hline Zona fasciculata & 55.40 & 54.29 \\
\hline Zona reticularis & 27.39 & 26.90 \\
\hline
\end{tabular}

Table 5: Histochemical reactions exhibited by the different components of the adrenal cortex of adult Bakerwali goat.

\begin{tabular}{|l|l|c|}
\hline \multicolumn{1}{|c|}{ Histochemical reaction } & \multicolumn{1}{|c|}{ Location in the adrenal gland } & Intensity \\
\hline \multirow{4}{*}{ PAS } & Cortex & ++ \\
\cline { 2 - 3 } & Zona glomerulosa & +++ \\
\cline { 2 - 3 } & Zona fasciculate & + \\
\cline { 2 - 3 } & Zona reticularis & + \\
\hline \multirow{5}{*}{ Sudan Black } & Cortex & ++ \\
\cline { 2 - 3 } & Zona glomerulosa & ++++ \\
\cline { 2 - 3 } & Zona fasciculate & ++ \\
\cline { 2 - 3 } & Zona reticularis & ++ \\
\hline \multirow{4}{*}{ Schultz reaction } & Cortex & ++ \\
\cline { 2 - 3 } & Zona glomerulosa & ++ \\
\cline { 2 - 3 } & Zona fasciculate & + \\
\cline { 2 - 3 } & Zona reticularis & + \\
\hline
\end{tabular}


towards medulla in Kano brown goat. Panchal et al. (1998) found that the zona fasciculate was identified by its radially arranged highly eosinophilic cells with round to oval nuclei in Marwari sheep.

The density of cells per unit field was greater in left adrenal gland (135.44 \pm 1.61$)$ (Table 2) while Kumar et al. (2009) recorded the low density of cells per unit area in zona fasciculate $(30.13 \pm 2.42)$. The cell size of zona fasciculata in left adrenal gland was $17.97 \pm 0.24 \mu \mathrm{m}$ whereas in right adrenal gland it was $16.35 \pm 0.27 \mu \mathrm{m}$ (Table 1) and the difference was statistically significant $(\mathrm{P}>0.05)$. Nama et al. $(2009 \mathrm{~b})$ found the average cell size and nuclear size of the zona fasciculate were larger than average cell and nuclear size of other two cortical zones in Marwari sheep. Kumar et al. (2009) observed that cell size of zona fasciculata was $6.22 \pm 0.41 \mu \mathrm{m}$ in buffalo. The diameter of nuclei of the cells of this zone was greater in left adrenal gland $(15.32 \pm 0.24 \mu \mathrm{m})($ Table 1$)$. The percentage of total cortical area occupied by this zone was $55.40 \%$ in right adrenal gland and $54.29 \%$ in left adrenal gland and the difference was statistically significant $(\mathrm{P}>0.05)$ (Table 3). Nama et al. (2009b) found that percentage of cortical area occupied by zona fasciculata was $47.24 \%$ in Marwari sheep. Kumar et al. (2009) found that the percentage contribution of zona fasciculate $(14.44 \%)$ was more than the zona glomerulosa $(6.23 \%)$ in buffalo. The percentage of area occupied by zona fasciculata was $59.40 \%$ in Teddy goats (Qureshi et al. 2012)

The zona fasciculata showed mild reactivity for carbohydrate as also reported by Kumar et al. (2011) in buffalo and mild reaction for cholesterol in contrast to findings of Kumar et al. (2011) and moderate reaction for the lipids in contrast to the findings of Kumar et al. (2011).

\section{Zona Reticularis}

The zona reticularis was the innermost and last zone of the adrenal cortex, lying deep to zona fasciculate and outer to adrenal medulla (Fig. 2). The cells of this zone were arranged in cords that projects in different direction arranged as a network of anastomosing cords and plates, separated by large sinusoids. Similar observations were made by Shehan et al. (2017) in local Iraqi goat. The cytoplasm of the cells of this zone was eosinophillic and the nuclei were basophilic. Collagen and reticular fibers were present in this zone. Nama et al. (2009b) described that the zona fasciculate cells in Marwari sheep resembled with the morphology and staining property of the cells of zona fasciculate but the cells formed anastomosing cords in contrast to zona fasciculate where they were arranged in columns. Panchal et al. (1998) found that the zona reticularis consisted of cuboidal to columnar shape cells and were arranged in irregular cords of cells entered into medulla in the adrenal gland of Marwari goat.

The zona reticularis was the second largest zone of the adrenal cortex. The cell size and nuclear diameter was also greater in left adrenal gland $(18.47 \pm 0.23 \mu \mathrm{m}$ and $16.00 \pm 0.19 \mu \mathrm{m})$ (Table 1). Nama et al. (2009b) found the cell and nuclear size of zona reticularis cells was $15.47 \pm 0.229 \mu \mathrm{m}$ and $5.785 \pm 0.304 \mu \mathrm{m}$ respectively in Marwari sheep. Density of cell per unit field in right adrenal gland was $124.23 \pm 0.80$ whereas in left adrenal gland it was 154.20 \pm 1.20 (Table 2). Kumar et al. (2009) reported that the density of cells per unit area was $33.03 \pm 3.42$ in adrenal gland of buffalo. The percentage of cortical area occupied by left adrenal gland was $26.90 \%$ and by right adrenal gland were $27.39 \%$ (Table 3). These values corroborate with the findings of Qureshi et al. (2012) in Teddy goats where the percentage of area occupied by zona reticularis was $27.90 \%$. Nama et al. (2009b) found that percentage of cortical area occupied by zona reticularis was only $4.11 \%$.

Mild to moderate reactivity was observed for carbohydrates, bound lipids and cholesterol in the zona fasciculata and zona reticularis of adrenal gland of adult Bakerwali goat (Table 4).

\section{Accessory Adrenal Cortical Nodules}

The accessory adrenal cortical nodules were observed microscopically in both adrenal glands of Bakerwali goat. These were round and oval in shape and cells were similar to adrenal cortical cells. The intracapsular (Fig. 8) and extracapsular accessory adrenal nodules (Fig. 9) were found in the present study. The adrenal nodules have been surrounded by the capsule of dense irregular connective tissue fibers mainly comprised of collagen fibers and reticular fibres. Similar results were given by Dangi et al. (2012) in Marwari sheep. The cells of the adrenal nodules were similar to the cells found in the zona glomerulosa. Medullary cells were not observed in adrenal nodules. Dangi et al. (2012) observed that the accessory adrenal cortical nodules resembled only with the cells of zona glomerulosa and no medullary tissue was found in accessory cortical nodules in Marwari sheep. Dangi et al. (2012) also described that the occurrence of extra capsular and intra capsular accessory adrenal cortical nodules in goat can be correlated with the fact that during development, groups of cortical cells remain entrapped in the capsule (intracapsular) and sometimes develop outside and adjacent to the main adrenal gland and form extra capsular accessory adrenal gland.

\section{Conclusion}

It is concluded that the shape index of left adrenal gland was significantly higher than the right one. Histologically, the adrenal cortex consisted of three zones namely zona glomerulosa, zona fasciculata and zona reticularis. Different micrometrical parameters were higher in left adrenal cortex than the right adrenalcortex. The 
zona glomerulosa exhibited intense reaction for mucopolysaccharide. Mild to moderate reactivity was observed for carbohydrates, bound lipids and cholesterol in the zona fasciculata and zona reticularis of adrenal gland of adult Bakerwali goat. The accessory adrenal cortical nodules were observed microscopically in both adrenal glands of Bakerwali goat.

\section{References}

1) Ahmadpanahi J, 2006. Anatomical and histological studies of accessory adrenal nodules in Caspian miniature horses. Turkish Journal of Veterinary and Animal Sciences 31(4): 275-278.

2) Ashok, N, Harshan, KR, Chungath, JJ, 2005. Morphometrical studies on the developing adrenal gland in crossbred goats (Capra hircus). Indian Journal of Animal Science, 75:1380-1381.

3) Bacha WJ, Bacha ML, 1990. Color Atlas of veterinary histology. $3^{\text {rd }}$ Edn. Wiley Blackwell.

4) Barnwal K, Sinha H, 1981. Gross anatomy of the organs of genital system in Black Bengal Goats. Indian Veterinary Journal, 63(2): 113-117.

5) Dangi A, Joshi S, Mathur R, Jangir DK, 2012. Extra-capsular and intra-capsular accessory adrenal Nodules in the adrenal gland of marwari goat. Veterinary Practitioner 13(1); 33-34.

6) Eurell JA, Frappier BL, 2006. Dellmann's textbook of veterinary histology. Wiley-Blackwell, 311-316.

7) Gupta JL, Bakshi SB, 2009. Sheep Development in Temperate region. Yak book publishers, Jammu, 151-153.

8) Kumar V, Sethi RS, Singh O, 2009. Micrometrical study on adrenal cortex during postnatal development in buffalo. Indian Veterinary Journal 86: 186-187.

9) Kumar V, Sethi RS, Singh O, 2011. Distribution of mucopolysaccharides in adrenal gland during postnatal development in buffalo. Indian Veterinary Journal 88(4): 53-55.

10) Luna LG, 1968. Manual of Histological Staining Methods of Armed Forces Institute of Pathology. III edn. McGrow-Hill Book Co., London, pp. 91-92.

11) Mallory FB, 1942. Pathological techniques.W.B.Saunders Co. Philadelphia.

12) Nama KG, Mathur R, Dangi A, 2009 a. Morphometrical studies on the adrenal glands of Marwari sheep (Ovis aries). Indian Journal of Veterinary Anatomy 21(1); 60-61.

13) Nama KG, Mathur R, Dangi A, 2009 b. Quantitative histological studies on parenchyma of adrenal glands of Marwari sheep (Ovis aries). Indian Journal of Veterinary Anatomy 21(2); 9-13.

14) Nandeshwar NC, Banubakode SB, Charjan RY, Mainde UP, Rana J, 2017. Biometrical studies on adrenal gland of goat in different age groups. International Journal of Science, Environment and Technology, 6(4): 2683-2687.

15) Nwaogu, Chima I, Francis, 2009. Morphological features of fetal and adult adrenal gland in Kano brown goats (Capra hircus). 2009. Animal Research International 6(1); 953-957.

16) Panchal KM, Vyas YL, Bhayani DM, Wadhwani KN, 1998. Histomorphological studies on the adrenal glands of the marwari sheep (Ovis aries). Indian Journal of Animal Sciences 68:1045-1046.

17) Ogbuewu IP, Ukaegbu FC, Odoemelam VU, Ugwuoke FO, Echereobia EC, Okoli IC, Iloeje MU 2016. Studies on the diversity of medicinal plant species utilized for goat reproduction in Abia State Nigeria. Journal of Livestock Science 7:1-12

18) Qureshi AS, Shah M, Rehan S, Pasha RH, Ullah HA, 2012. Histomorphometrical investigations on the heart, kidneys and adrenal glands in normal Teddy Goats (Capra hircus) using image analysis system. Pakistan Veterinary Journal ISSN: 0253-8318 (Print), 2074-7764 (Online).

19) Salvaña FRP, Sepelagio EG, Sanchez CB, Besana CM, Kamamang JS, Cardenas LB 2019. Inventory and diversity of forages utilized by farmers raising goats in Halal way: The case of Region XII, Philippines. Journal of Livestock Science 10:118-125 doi. 10.33259/JLivestSci.2019.118-125

20) Sanyal S, Das PK, Ghosh PR, Das P, Das BC, Gupta RK, 2005.Micromorphological structure of adrenal cortex of black Bengal goat (Capra hircus). Indian Journal of Animal Health 44:167-169.

21) Sastry NSR, Thomas CK, 2005. Livestock production and management. IV edn. Kalyani Publisher, New Delhi.332.

22) Shehan NA, Hussein HA, Hussein SS, 2017. Histological and histochemical study of adrenal gland in local Iraqi goats (Capra aegagrus). International Journal of Science and Technology 12(4): 22-27.

23) Singh UB, Sulochana S, 1978. Laboratory Manual of Histological and Histochemical Techniques. Kothari Medical Publishing House.Bombay, pp. 22.

24) Wheater GH, Burkitt HG, Daniels VG, 1994. Wheater's functional histology. $3^{\text {rd }}$ edn. Churchill Livingstone. pp. $313-31$ 